Saeeda Shab 51

\title{
Management Development: a serious concern
}

\section{Saeeda Shah"}

In this age of globalisation, multiple pressures are intensifying for the under developed and developing countries. It is a struggle for economic survival, where the larger fish will eat up any small fish not clever enough to learn the rules of the game. In this market oriented competitive world, management development has increasingly become linked with economic output. Additionally, education is no more just an intellectual exercise. It is compulsively being recognised as a large sector of human and financial resources, requiring strategic management and a purposeful development of the concerned personnel for quality and effectiveness.

This paper is based on my Ph.D. study focusing on education management (Shah: 1998). It provides a discussion of the concept of management development and some concerned approaches. The relationship between 'management' and 'development' in the present day context of 'change' is highlighted to emphasise the need for serious and meaningful policy in the area. Issues faced in education management are analysed as indicative of lack of relevant expertise, and the significance of contextual factors is emphasised in educational planning and management for improved output.

\section{Introduction}

Management development is a contested area of theorising, and draws from relevant management concepts and organisational theory. The notion evolved from an industrial context where it was perceived as contributive to increased output. Stress on economic orientation and accountability in education emphasised the need for management development in education (Fullan:1993; Green:1994; Middlehurst:1995a; 1995b; Reeves:1995). The perception of educational institutions as organisations with specific aims, and "management development as an integral part of the process of orgnisational development" (Mullins: 1995:682) lent great stress to management development. It linked organisational development with management effectiveness and output, requiring development of management potential to achieve the intended aims.

\footnotetext{
* Dr. Saeeda Shah is Dean, University College of Home Economics, Mirpur, Azad Kashmir.
} 


\section{An Overview}

In the developed world, the flux of literature concerning management development and training from the 1970s onwards was a response to the increasing complexity and diversity of educational institutions, and the economic, social and political elements leading to these developments. In Britain, "government sponsored research and policy initiatives provided a major impetus to educational management studies and training" (Preedy:1989:3). Development of BEMAS around the same time also points to the increasing demands and interest in the area. DES $3 / 83$ and DES 1987 explicitly conveyed government policy regarding management development in educational institutions and linked it with economic development.

Research programmes focusing on needs analysis of educational managers highlighted the unpreparedness of personnel appointed as institutional managers. In a study of managers from ten universities and university colleges in Britain, Cuthbert et al reported confusion and lack of preparation for management mentioned by their respondents $(1987: 24)$. They perceived management development as "an attempt to improve management effectiveness through a planned and deliberate learning process ---- to improve educational practice by improving manager's performance" (Ibid:10). Educational progression to a considerable extent depends on the capabilities of the administrative heads to execute and support the developmental and implementation phases. In broad terms, management development implies improvement of management potential and effectiveness. Chambers et al define management potential as "the capacity to make intended and accepted things happen through the use of given resources" (1990:12) and explain 'development' as implying "improvement, becoming more accomplished, bettering oneself” (Ibid:14).

Management development is not necessarily linked with knowledge gained through formal education, or skills learned through specific training, although these can be contributory factors besides many others. It is often used as a blanket term inclusive of relevant experience, education and training. Middlehurst provides an interpretation of the three terms management education, training, and development - given by Constable and McCormic (1987), who describe management education as formal qualifications, management training as formal learning activities, and management development as "broader still, job experience and learning from others" (Middlehurst:1995b:98,99). The meanings often vary in actual applications. Cuthbert et al observe that among senior management staff, training is "narrowly conceived as skills and task based; as being appropriate to career formations rather than senior positions. Development, on the 
other hand, carries associations with experience and continuous learning" $(: 1987: 239)$.

Ideally, management development in education should aim at improving performance and effectiveness: individual effectiveness and organisational improvement (Mullins: 1995:682); and also 'pupil performance' (Ballinger:1986:10). An increasing emphasis on the interrelationship between management development and the institution's development and output (Brew:1995), and claims that the task of education will be compromised without effective management (Burnham:1994:25) indicate the direction of the argument. Middlehurst takes a very explicit stand:

"poor management at the top .... directly effects the capacity and the motivation of individuals and groups to teach, research and to learn to their fullest potential" (1995b:106).

This requires a brief discussion of the phasing and processes of development.

\section{Development Approaches}

There is a high consensus on the need for training and development of institutional heads at the induction stage as a process of "orientation to new roles" (Middlehurst 1993:176). Many studies recommend development opportunities for managers to enhance their confidence in their ability to take on a new job (Lund:1990; Middlehurst:1995b; O’Neil:1995). However, the work context needs to be considered when planning approaches to training and development (Middlehurst:1995:98). Political and ideological approaches towards education greatly influence the nature of development policies and strategies. Accordingly, development activities can consist of very structured and specific programmes concentrating on learning a particular process or skill/s, or these may be intended to enhance resourcefulness and preparedness through increased understanding and insight, helping an individual to realise his/her full potential to manage in a way that allows for the individuality of the person and which enhances effectiveness within a particular context.

The management development model suggested by Bolam (1987) demonstrates that there are distinct development needs not only at induction but in relation to the whole career and also in terms of stages within a particular post:

the preparation stage (when they wish to apply for a new post) 
the appointment stage (when they are selected or rejected)

the induction stage (e.g. first two years in a post)

the in-service stage (e.g. 3-5, 6-10, 11+ years in a post)

the transitional stage (i.e. promotion, re-deployment, retirement)

The emphasis is not just on preparing for the new job, but on continuous development and support programmes for effectiveness. Any perception of training and development "as a means of rectifying deficiencies" (Middlehurst: 1995b:109), or a help "to jump the ... hurdles" (Legotlo and Westhuizen: 1996:409) ignores the complex management contexts of educational institutions which require "sustained development rather than short-term patching up operations" (Brew: 1995:5). Middlehurst makes a very succinct statement:

"given the breadth of these tasks, it is obvious that narrowly conceived and short-term training will not be sufficient to prepare individuals for senior roles or to support them when in a post, .... it is also clear that some preparation and continuing development will be required" (1995b:103).

Stressing continuing training and development for institutional managers', he strongly argues against the dangerous assumption that those who reach the pinnacle of their organisations - i.e. institutional heads, principals and others - no longer require further training or development. He proposes "an approach which embraces continuing and active participation in learning at all levels of organisation, including the top" (1995:98). In his opinion, lack of formal management education among university staff has strong implications for the design of management training and development opportunities' (Ibid:99). Middlehurst favours a 'holistic view of management learning', with an emphasis on 'renewal':

"to remain intellectually stimulated and challenged, to maintain a breadth of vision and perspective, to achieve personal and professional refreshment (to stave off physical and psychological stress ${ }^{1}$ ), to sustain outside contacts or to overcome isolation and institutional introversion" (1990:114,5).

To achieve this ongoing development, Middlehurst considers three types of learning processes for institutional heads (1993:174).

\footnotetext{
${ }^{1}$ There is an abundance of recent literature on job stress; i.e. Farber:1991; Grady:1989; Ostell:1995; Quick:1990; Rogers:1996; for referencing see Shah:1998.
} 
- informal managerial (in job experience);

- integrated managerial (through feed back on performance); and

- formal managerial (formal management development).

Learning through experience is in line with the famous Chinese proverb: I do and I understand. It has particular relevance for contexts like Pakistan with specific traditions and philosophy of education, and an absence of relevant management development programmes. In such situations, experience is often the only available mode of learning. Generally, learning through experience is perceived as a natural process but it has limitations, and as Bush maintains:

"Disastrous errors of judgement can occur while experience is being gained. Mistakes are both costly in material and human terms"; and he further quotes Jennings (1977:vii) that "wise men do not have to learn of the existence of every brick wall by banging their nose into it” (Bush:1994:34).

Burgoyne argues that natural management processes take place in all organisations, can work in the start, but cannot work for all sorts of organisations and cannot be clung to beyond its time (1988). It relies on experience, and on how experience is perceived and used. Dewey's theory of experiential learning presents a cyclical process where experience and practice feed into each other. Discussing his theory, Osterman and Kottkamp (1993) argue that experience is a basis for learning but it requires reflection to serve as a learning process ${ }^{2}$. Boud et al also maintain that "while experience may be the foundation of learning, it does not necessarily lead to it: there needs to be active engagement with it" (1993:9). Learning from experience is not a linear process; it is learning and un-learning, and re-working: "Experience has to be arrested, examined, analysed, considered and negated in order to shift it to knowledge" (Criticos: 1993:161). Criticos stresses the significance of reflection and reflexivity by explaining the value of the intellectual growth that follows the process of reflecting on experience, emphasising that "effective learning does not follow from a positive experience but from effective reflection" (1993:162).

Schon defines reflective practice as "a dialogue of thinking and doing through which I become more skillful” (1987:34). This dialogue is simultaneous where:

${ }^{2}$ Elana Michelson highlights the distinction between 'experience' and 'reflection' in adult learning theory, which explains experience as the raw material for learning and reflection as a highly cognitive processing stage in which the learning actually takes place (1996). 
"The reflective practitioner assumes a dual stance, being on the one hand, the actor in a drama, and on the other hand, the critic who sits in the audience watching and analysing the entire performance" (Osterman and Kottkamp: 1993:19).

Management development programmes are generally linked with management theories (Bush:1994), and shape the training approaches. The notion of development is constructed by the ideological, political, social and economic factors on one level, and on another level, management concept, organisational ethos and learning approaches shape it in articulation with the specific contextual needs.

In view of the diversity and plurality of management situations, the emphasis on training needs of institutional heads ${ }^{3}$ appears linked with a consideration of the specific ethos of educational institutions and the uniqueness of each management context (Gray:1980; 1982; Greenfield:1993; Hodgkinson:1991). Training people to replicate, or apply borrowed 'management techniques' (Gray: 1980:14) cannot be effective in education where each management situation is unique. Lund sees it as "a shift from a purely skill based approach to an emphasis on the personal development of the manager" (1990:41). Gray stresses and I agree that:

"if we are to train people to manage, we must train them not to learn and remember what others have thought but to think and decide for themselves” (1982:8).

For the purposes of development, management skills can be defined as "both specific to organisations, applicable only on site, yet general enough to admit of technical training and preparation ..." (Hodgkinson: 1991:53). The areas emphasised might differ in different contexts or may have diverse priority levels, and the learning approaches deemed effective may vary but there is a high consensus in literature on the need for management development. Certainly there are barriers of time and resources for development (Cuthbert et al: 1987:239; Burnham: 1994:93), considering the size of the education sector, but the stress on the need is unanimous.

\section{Management of Change}

In today's context of economic constraints and global pressures, academic excellence cannot suffice to cope with the changing economic

3 See Cardno and Piggot-Irvine:1996: Coombe Lodge:1994: Crawford et al:1997; Cuthbert et al:1987; Day:1991; 1993; Hughes:1982; Lund:1990; McNay:1988; Middlehurst:1993; 1995; O’Neil:1995; Thackwray:1994 and Watson:1988 for emphasis on training needs of institutional heads. 
situations. It requires the development of relevant expertise. Besides, the process of change is pervasive and dynamic. The need to manage 'change and improvement with shrinking resources in turbulent times' (Busher and Smith: 1993:1) is emerging as a compelling theme in educational management. Vast literature on management of change bears evidence to the phenomenon. The snowball process of change has been increasingly gaining speed and size, demanding the strategic management of financial and physical resources (Fullan:1991; Green:1994; Leigh:1994; Reeves:1995; Weil:1994). Bush and West-Burnham admit that due to the rapid pace of change "college managers have to absorb and interpret externally imposed change while facilitating internal innovations" and to this purpose they need a 'fire fighting' approach accompanied by a 'vision' (1994:3). The Coombe Lodge Report (1994) conveys an awareness of rapid change with increasing demands on management, which not only requires a re-consideration of management theories and leadership styles but also necessitates the development of those responsible for management.

The manager is the new focus, and the shift of focus from teacher to the manager is indicative of the change where education is increasingly exposed to market forces and global effects. The emphasis on the institutional heads as the agents of change has been increasing (Fullan: 1991:152). Discussing different initiatives towards this end in the USA and Canada, Fullan emphasises that the need for professional development of leaders is more important than staff development because of its 'strategic importance' (Ibid:336-9). He perceives the "principals as gatekeepers or facilitators of change" (1993:11) who need to be prepared to manage it to the fullest of their abilities, in the best interest of organisational goals. The change can be initiated, or "imposed and unprecedented" (Newton and Tarrant: 1992:1), and in both cases requires sensitive management. It can be stressful (Ibid:205) if there is disparity between job and ability $^{4}$, leading to failure of implementing change as it did in the case of privatisation of selected institutions in Pakistan. Burnham claims that:

"the reason why educational changes are often perceived as so problematic is not the nature of change itself but the nature of the knowledge, skills and attitudes of those involved and the way that these are exposed in action" (1994:93).

Management development is a coping strategy. Management development of those occupying key leadership positions in view of changes

\footnotetext{
${ }^{4}$ A definition of stress offered by Cox (1989) is that it is a "phenomenon arising from a comparison between the demand made on a person and ability to cope". The disparity is perceived as stressful.
} 
in institutions and the educational sector gains importance in order to conduct change and development (Lyons: 1993:119; also 1982). Increasingly, the future education sector is "being forced by external pressure from a service to a business orientation which is having an impact upon management strategies and styles" (E1liott and Crossley: 1997:88; E1liot and Hal: 1994:5). The inability of the educational managers to manage in the new context cannot change the requirements but it may lead to the exploration of other options to satisfy the need. Back in 1988, Lewis C., Principal Swansea College, wondered prophetically "whether by 1995 the principal will have become a managing director"; and now there are advertisements in Europe for principals/vice-principals asking for a "generic management qualification such as the MBA" (Elliot and Hall: 1994:6). There is an ongoing debate in the area, maintaining that if principals do not have a background in education, quality of education and the special ethos of the educational institutions may suffer; and second, the practice may prove a barrier to teachers' promotions and affect teachers' motivation. This supports the argument to develop the management potential of the people from an educational background, 'who often lack in formal management education' (Middlehurst:1995b), to meet the ever increasing challenges of the time, and to maintain and improve the quality of education.

The requirements of change have emphasised interdependence between education and economic development, and demand that "education must be accountable and managed for the economic good" (Slatter:1994). In Pakistan, a changed orientation of educational aims is being constructed under global pressures asking for a new approach in management. The efforts to lead colleges towards financial autonomy marked the impact of change (Iqbal and Davies: 1994), and the doubts in managing financial autonomy pointed to the need for expertise in finance management. The predicament of concerned managers was equal to that of novice swimmers thrown against strong currents and flailing desperately for survival. In this case they had to be rescued by the government through retraction of the process ( Jang. 1997). It shows that management of colleges has become a complex activity, which "cannot be left to chance, or to ambitious and enthusiastic individuals taking the initiative on their own behalf" (Bullock et al: 1995; 1994). It is an area of serious policy and application.

Another dimension of the issue is that change is not always welcome or necessarily developmental (Fullan:1991; Nisbet:1980; Schon:1971). Fullan argues that it can be stressful and problematic, involving anxiety, loss, and resistance from people, individuals and organisations, as it seemed in the case of Pakistan (Iqbal and Davies: 1994). Professional unpreparedness in such situations can be damaging for the managers, the managed and the 
organisations. Greenfield rightly questions the tendency to ignore management development:

"why do we merely throw people at these jobs, expecting them to do well with almost no experience of them, offering them no analysis of their experience" (1993:258).

It is increasingly viewed as a waste to leave "the resources and students in the hands of a person unprepared or untrained to handle" (Coulson:1990). Speaking from a developing country perspective, although from a school context, Legotlo and Westhuizen write:

"Gone are the days of trial-and-error and swim-or-sink induction strategies. Without specific attention to the effective management development programmes for school principals, such as the well-planned comprehensive induction programmes for new principals, most of the attempts at improving the quality of education in developing countries will remain a pipedream" (1996:410).

In the higher education context, Middlehurst (1995b) stresses a necessary supporting framework for management and leadership development through courses, seminars and workshops. He maintains that although the new heads are not exactly without management experience of some sort, but for many individuals the entry to senior posts involves a transition from operational to strategic management levels (Middlehurst: 1995b:106). Therefore an assessment and provision of relevant 'competence' becomes essential to ensure optimum performance and effectiveness from this transition.

\section{Pakistani Context}

The education sector in Pakistan, according to my study, is conspicuous by virtue of the dearth of literature on management development, and also for lack of development facilities for educational managers in particular. A strong emphasis on this need has been voiced in government reports and by occasional educationists (Iqbal:1981; UNESCO: 1981; UNESCO: 1984) from as early as 1959 (Report of the National ... :1959), but it was virtually by the mid-seventies that the government began to realise the economic realities and the after-effects of quantitative expansion of 'higher education minus quality management'. In 1980, a UNESCO meeting of the educational administrators and key personnel from eleven South East Asian countries was held at Seoul to discuss "Innovations in Education". The major emphasis was on the preparation of principals, heads of schools, administrators, and key-personnel, who could introduce 
and implement those innovations. This reflected an understanding of the fact that without developing the skills of the people immediately responsible for delivering education, improvements and quality could not be achieved. This meeting was a formal acceptance of the importance of institutional management and the need to develop it. In-depth discussions were undertaken to identify the issues and to prepare guidelines for the training of key-personnel (UNESCO Report:1981). The signals from the World Bank that "money is not and will not for a long time to come be available for everything" (Hulten: 1986:12) increased the demand for effective management. Hultin mentions the World Bank's education policy paper for 1980 which suggested along with other things that:

"the education system should try to achieve maximum internal efficiency through the management, allocation, and use of resources available for increasing the quantity, and improving the quality of education" (1986:2).

In spite of a large expansion of educational institutions, the situation in Pakistan in the 1980s was summed up as:

an increase in unemployment, particularly among unemployed graduates;

non-exploitation of national resources;

a general decline in the quality of education;

a large shortfall in the availability of scientific manpower; and

absence of an integrated information system to co-ordinate higher education with national manpower requirements (Faraj:1988).

Such findings unveiled the disparities between policy-making and implementation. Criticism from within the country, and from the foreign funding bodies resulted in a shift in government policy, emphasising the role of education in developing manpower for different levels of the economy and the role of institutional managers in achieving these objectives. This directed focus on educational management which was further reinforced by the findings that inadequate management, lack of familiarity with the task and lack of trained management personnel (Hayes: 1987:78-97) were among the causes of deteriorating academic standards and the failure of educational reforms.

In Pakistan, policy making and planning work in a linear process, from top to bottom, and those planning at the top are mostly unaware of the realities of the actual educational situation, or of the implications 
involved in the implementation of educational changes (Iqba1:1981; Hayes:1987). The recent trend towards institutional autonomy in several countries found its way in Pakistan as well, but only at the experimental leve1. Following a World Bank Report (1989) for Pakistan, "to consider the current circumstances and future development of education", which recommended that "some colleges should be accredited with full operational autonomy", four prestigious institutions, male and female, in the province of Punjab were declared to be 'autonomous institutions', mentioned above. A study carried out by Zafar Iqbal and Lynn Davies in 1992-3, to evaluate the early impact of these changes expressed the concerns of the teaching staff about the whole process (Iqbal and Davies: 1994). They also wrote that senior management and staff perceived no evidence of finances coming to the institution from any source, except government funding and feared financial difficulties as the major stumbling block to any progress towards real autonomy. Here, lack of relevant competence proved a stumbling block in the management of change.

The argument develops that if the senior management of these institutions had been trained and developed in view of the intended goals, this grant of autonomy might have worked better towards achieving improvement of the finances, and the quality of education, as is happening in the developed world. The practice of imposing a situation without working out all the details, and without preparing the key personnel responsible for managing it, meant that even the best plans could not attain the desired goals. Moreover, the world wide economic recession has imposed restraints on budgets. A country such as Pakistan can hardly afford to put huge amounts of money into education ${ }^{5}$ as it was in the seventies, without some quality assurance and making education responsive to economic needs. This highlights the need for management of resources and change.

In addition to that, a major area of development in the present day context is interpersonal relations. "It is not only useful in policy-making, planning and conduct of activities but also develops political skills such as the ability to understand and develop power relationships or build coalitions" (Kotter:1988). It is a socio-political skill which enhances the support of those "above and below us". In Pakistan, political changes, power-play, and corruption, coupled with socio-cultural pressures ${ }^{6}$ make

${ }^{5}$ The educational expenditure in Pakistan is a little above 2 per cent of the GNP (UNESCO Yearbook: 1995:1-5), which is very low as compared to other developing countries.

${ }^{6}$ Robert Kiltgard (1979) in a study carried out in Karachi, and Adele Jones (1991), in research conducted in Peshawar, Pakistan, refer to this corruption and power-play permeating through the educational context, although not in direct reference to institutional management. 
management a hard task in itself. In the circumstances, it can be argued that professional competence and development of management skills in the relevant areas might improve the ability and effectiveness of the college heads, adding to their strength and confidence to manipulate interference in an effective way to achieve the target goals.

One more problem area is finance management. In my study, headship was perceived by the heads as finance-centred and control over money. Interestingly, even those college heads who opined that management was learned in the field insisted that training in finance must be provided prior to appointment:

"The department should arrange for training in finance. It is a skill. If you don't have it you incur a bad name ---- that you have swindled, that there is a fraud; even if you have been perfectly honest. It is a punishment for not knowing. Keeping a check is very demanding ...." (PM2).

The emphasis on finance training seemed to arise from a shared belief that "as long as you do not know a job yourself you cannot make others do it for you properly. Your subordinate will work better if he knows that you know it" (PM5). Besides a 'broadening of vision' (Middlehurst: 1993; 1995; Greenfield: 1993), managers do need "a balance of technical, social and conceptual knowledge and skill, acquired through a blend of education and experience" Mullins: 1995:681. Lyons suggests three areas for management development:

1. substantive concerns-both theoretical and research;

2. socio political concerns-policy-making and resource allocation;

3. technical professional concerns-planning and conduct of activities.

An awareness of these issues is increasing in Pakistan, but still the development of educational administrators remains a neglected area. According to the institutional heads, coming to this job without being prepared for it reduces job-effectiveness, delays processes, and increases possibilities of errors and omissions. My research participants emphasised the need for comprehensive, pre-induction training. Learning-on-the-job was described as a hard and distressing experience:

"There should be training facilities. Although I never had any training, I think that there are certain things with the changing times, that we 
do not understand. Training can bring an awareness of new things and developments. .... It can make our job easier" (PF4).

However, development and training of institutional heads appeared to be a peripheral issue in the policy-making-politicians' domain, in spite of emphasised importance of the higher education sector and its admitted relationship with national development. Policy-making or absence of relevant policy making emerged as a political phenomenon ${ }^{7}$. According to the concerned managers:

"Our resources are limited and also there are political compulsions. There is demand and need for staff development. It should be given priority. But when a politician (in power) says 'give a college to that area, or upgrade that inter college into degree or science college', our meagre resources are diverted towards that. Politicians have their own priorities. Even officers in our positions, are not the real policy-makers; it is the politicians' domain" (PSM4).

And often this domain is mismanaged itself. Even when policies are formed in policy statements, these fail to materialise because of the issues of pragmatics, feasibility, practicality, implementation, etc. The requirement is that policy-making should be treated as a professionals' domain, and those who are to implement these policies - i.e. educational managers - should be prepared for this task. Ignoring management development in this large public sector will ultimately be a national disaster.

\footnotetext{
${ }^{7}$ For details please see Shah: 1998: chap 6.
} 


\section{References}

Ballinger, Elizabeth: 1986: The Training and Management Needs of Managers: An Overview in Staff development in the secondary school: management perspectives, (eds) Chris Day and Roger Moore. London: Croom Helm; pp 9-31.

Bennett, N; Glatter, R and Levacie, R: 1994: Improving Educational Management Through Research and Consultancy. London: Paul Chapman and OUP.

Bolam, R 1997: 'Management Development for Headteachers: Retrospect and Prospect', in Educational Management and Administration: Vol 25, No. 3, 1997. Pp 265-284.

Boud, D; Cohen, R and Walker, D (eds): 1993: Using Experience for Learning. SRHE and OU Press.

Brew, A (ed): 1995: Directions in Staff Development. Buckingham Society for Research into Higher Education (SRHE) and OU Press.

Bullock, Kate: James, Chris and Jamieson, Ian: 1995: 'An Exploratory Study of Novices and Experts in Educational Management', in Educational Management and Administration: Vo1 23, No. 3; pp 197-205.

Bullock, Kate: James, Chris and Jamieson, Ian: 1994: The Process of Educational Management Learning Paper presented to BEMAS Annual Conference, September 1994; pp 1-11.

Burgoyne, J: 1988: 'Management Development for the Individual and the Organisation', in Personnel Management; Vo1 20, No. 6; pp 40-45.

Burnham, W.J: 1994: 'Management in educational organisations', in Bush, T and Burnham, W.J. (eds): 1994: The Principals of Educational Management. Longman: EMDU; pp 9-32.

Bush, T: 1994: 'Theory and Practice in Educational Management', in Bush T and Burnham, W.J. (eds): 1994; op cited; pp 33-53.

Busher, H and Smith, M (eds): 1993: Managing educational institutions: Reviewing Development and Learning. Sheffield Hallam University: BEMAS. 
Cardno, C and Piggot-Irvine, E: 1996: 'Incorporating action research in school senior management training', in International Journal of Educational Management: Vol 10, 5.

Chambers, Charlotte: 1990: Develop your management potential: a self help guide / Charlotte Chambers, John Coopey and Adrian McLean. London: Kogan Page with Association for Management Education and Development.

Coombe Lodge Report: 1994: "Changing the Culture of a College', in Vo1 24, No. 3.

Coulson, Alan: 'Primary school headship', in Saran, R and Trafford, V (eds): 1990: Research in Education Management and Policy. London: Falmer; pp 101-107.

Cox, T: 1989: Stress. Nottingham: Nottingham University Stress Research Unit. Nottingham.

Crawford, M; Kydd, Lesley and Riches, C (eds): 1997: Professional development for educational management. Buckingham: Open University Press.

Criticos, C: 1993: 'Experiential Learning ...', in Boud, D; Cohen, R and Walker, D (eds): 1993: Using Experience for Learning. SRHE and OUP: pp 157-168.

Cuthbert, R; Pike, J and Trafford, V: 1987: DIY: A Manual for Locally Based College management development. York: Longman for FEU Publications.

Day, C: 1991: 'Roles and Relationships in Qualitative Research on Teachers' Thinking: A Reconstruction', in Teaching and Teacher Education: Vo1 7. No. 5/6; pp 537-547.

DES 3/83: The In-Service Teacher Training Grant Scheme. London, HMSO.

DES 1987: Maintained FE: Financing, governance and law; London: DES.

Elliott, G and Crossley, M: 1997: 'Contested Values in Further Education', in Educational Management and Administration: Vo1 25, No. 1; pp 79-92.

Elliott, G; Hall, V: 1994: 'FE Inc. Business orientation in Further Education and the introduction of human resource management', in School Organisation: Vol 14, No. 1; pp 3-10. 
Faraj, A.H: 1988: "Higher Education and Economic Development in South Asian Countries', in Higher Education Review: Vol. 21, No. 1; pp 9-28.

Fullan, Michael: 1993 Change forces: probing the depths of educational reform. London: Falmer Press.

Fullan, M with Stiegebauer, S: 1991: The New Meaning of Educational Change. London: Cassell.

Gray, H.L: 1980: Management in Education: Working Papers in the Social Philosophy of Educational Institutions. Driffield: Nefferton Books.

Gray, H.L: 'A Perspective on Organisation Theory' in Gray, H.L. (ed): 1982: The Management of Educational Institutions: Theory, Research and Consultancy Lewes: Falmer Press; pp 29-43.

Green, D. (ed): 1994: What is Quality in Higher Education? Buckingham: SRHE and OUP.

Greenfield, T and Ribbions, P (eds): 1993: Educational Administration: Towards A Humane Science. Routledge: London, New York.

Hayes, L.D: 1987: The Crisis of Education in Pakistan. Vanguard, Lahore: Pakistan.

Hodgkinson, C: 1993: Forward to Greenfield and Ribbins: 1993; op cited.

Hultin, M: 1986: 'The Role of Cross-National Research in World Bank Education Operations', in Postlethwaite T.N. (ed): 1986: International Educational Research. Oxford: Pergamon Press; pp 118.

Iqbal, M: 1981: Education in Pakistan. Aziz Publishers; Lahore: Pakistan.

Iqbal, Z and Davies, L: 1994: 'The Early Impact of the Grant of Autonomy to Educational Institutions in Pakistan', in Journal of Education Policy: Vo1 9, No. 3; pp 197-210.

Jones, A.M: 1991: 'Community Participation in Frontier Education Planning', in Educational Management and Planning. Vo1. 19, No. 3; pp 160-165.

Klitgaard, R.E: 1979: 'Merit and Admission Policy: Case Studies from Pakistan', in Comparative Education Review: Vol 23, No. 2; pp 271-282.

Kotter, J.P: 1988: The leadership factor. New York: Free Press. 
Leigh, Andrew: 1994: 'Change and Leadership', in Bennett et al (eds): 1994, op cited; pp 11-26.

Legotlo, M and Westhuizen, P: 1996: 'Coming on Board: Problems Facing New Principals in Developing Countries', in Educational Management and Administration; Sage Publications: Vol 24(4) 401-410.

Lund, Graham: 1990: Educational management: research to identify the educational management development and training needs of primary headteachers and deputy headteachers. Thesis (M.Phil.) - University of Nottingham.

Lyons, G. and Webbs, P.C: 1982: 'The Nature of Managerial Activities in Education', in H.L. Gray (ed): 1982, op cited; pp 85-108.

Lyons, G: 1993: 'Human Resource Development', in Busher, H and Smith, M (eds): 1993, op cited; pp 118-133.

Michelson, Elana: 1996: 'Usual suspects: experience, reflection and the (en) gendering of knowledge', in International Journal of Lifelong Education: Vol 15, No. 6, pp 438-454.

McNay, Ian: 1988: Coping with Crisis: Management Development in FHE. London: Longman for FEU Publications.

Middlehurst, R: 1990: 'Leadership development in Universities', in Saran. R and Trafford, V (eds): 1990: Research in Education Management and Policy. London: Falmer; pp 115-121.

Middlehurst, R: 1993: Leading Academics. Buckingham. SRHE and OUP.

Middlehurst, R: 1995a: 'Leadership, Quality and Institutional Effectiveness', in Higher Education Quarterly: Vol 49, No. 3; pp 267-284.

Middlehurst, R: 199b: 'Top-Training: Development for Institutional Managers" in Brew A (ed): 1995, op cited: pp 98-117.

Mullins, L.J: 1995: Management and Organisational Behaviour. London: Pitman.

Newton, C and Tarrant, T: 1992: Managing Change in Schools. London: Routledge.

Nisbet, R: 1980: The History of the Idea of Progress. New York: Basic Books. 
O'Neil, J: 1995: 'Whose job is it anyway: the team leader as catelyst for management development', in Educational Management and Administration: Vol 23, No. 1: pp 19-27.

Osterman, K and Kottkamp, R: 1993: Reflective Practice for Educators. Corwin Press.

Preedy, M (ed): 1989: Teachers Case Studies in Educational Management. London: Paul Chapman.

Reeves, F: 1995: The Modernity of Further Education: The Direction of Change in Further Education Colleges. Bilston: Bilston College in Association with Education NOW.

Report of the Commission on National Education: 1961: Government of Pakistan, Ministry of Education, Government of Pakistan Press, Karachi: Pakistan.

Schon, D.A: 1971: Beyond the Stable State. New York: Norton.

Schon, Donald A: 1987: Educating the reflective practitioner: [toward a new design for teaching and learning in the professions]. San Francisco: Jossey-Bass.

Shah: 1998: Educational Management .... : Ph.D. thesis at the University of Nothingham: England.

Thackwray, Bob: 1994: 'University Staff: A worthwhile Investment', in Knight, P.T. (ed): 1994, op cited; University-wide Change, Staff and Curriculum. Edgbaston: SEDA Publications; pp 71-77.

Jang (Urdu), London, April 18, 1997, p-2, a statement by The Chief Minister Punjab, Pakistan.

UNESCO Report: 1981: UNESCO Regional Office for Education in Asia and the Pacific. Bangkok, Thailand.

UNESCO Report: 1984: Diagnostic Studies in Educational Management: Country Pakistan, UNESCO Regional Office, Bangkok, Thailand.

Watson, K: 1988: 'Forty Years of Education and Development,' in Educational Review: Vo1 40, No. 2; pp 137-174.

Weil, Susan (ed): 1994: Introducing change 'from the top' in universities and colleges: 10 personal accounts. London: Kogan Page. 